\title{
SHEAR-WAVE TRAVEL TIMES FROM SS
}

\author{
By RhetT ButLer
}

\begin{abstract}
The seismic shear phase $S S$ is considered as a tool in the reconnaissance of the Earth. The Hibert transform is empirically verified as a reasonable mimic of the distortion incurred at the internal caustic in the propagation of SS. Travel times are obtained by a waveform correlation technique for 26 well-recorded SHSH waves from the 1968 Borrego Mountain earthquake. Significant variation is found in the travel-time residuals for paths reflected under the Canadian shield. A correlation of the variation with tectonic sub-province is suggested. The data are sufficiently precise to indicate lateral heterogeneity of several percent in the upper mantle velocities within the Canadian shield.
\end{abstract}

\section{INTRODUCTION}

The relatively fixed distribution of sources and receivers used in the study of the Earth's interior is a fundamental impediment to progress in seismology today. Sources in new locations are impractical, since, to be useful, they must be nuclear explosions. Ocean bottom seismometers are an alternative to the fixed, land based receivers. However, until employment of sufficient numbers is accomplished and enough large events are recorded, their contribution will be small.

The study of the shear phase $S c S$ has opened a novel approach to bridging the impediment: $S c S_{n}$ in its traverse from source to core to free surface to core to receiver samples an intermediary portion of the Earth. Multiple $S c S$ travel times (Okal and Anderson, 1975; Sipkin and Jordan, 1975, 1976; Butler 1977; Okal, 1978) and attenuation data (Jordan and Sipkin, 1977) have provided much information on the lateral variation of the Earth's properties and fuel for mantle dynamical theory (Jordan, 1975a, b).

The purpose of this paper is to document preliminary results in the development of the seismic shear phase SS as an Earth reconnaissance tool. SS is a shear wave which reflects once off the Earth's free surface at the midpoint of its propagation path. However, due to distortion effects in its propagation, analysis of $S S$ is not as straightforward as $S c S$.

The development of $S S$ as a useful seismological tool is a natural progression from our increasing experience with waveform modeling of body waves. This experience is manifested in two ways: (1) our understanding of and ability to model earthquake sources, and (2) the capability of using these now known sources to study propagation problems in the Earth.

In recent years a technique has been developed using generalized ray theory to determine detailed fault parameters for shallow events based on waveforms of teleseismic body phases. The method uses a modified ray theory which includes crustal phases at the source- $P, p P, s P$, etc.-as well as crustal interactions at the receiver. Long-period waveforms are then synthesized and compared with the observed in the time domain using a correlation operator. Fault orientation such as strike, dip, and rake, as well as focal depth and source-time duration are estimated based on the fit to the data, which generally includes waveforms as a function of azimuth and takeoff angle. The technique has been successfully applied to about two dozen events. Recent literature includes: 1967 Koyna, India earthquake (Langs- 
ton, 1976); Borrego Mountain (Burdick and Mellman, 1976); Oroville earthquake (Langston and Butler, 1976); Puget Sound earthquake of 1965 (Langston and Blum, 1977); Truckee earthquake (Burdick, 1977); San Fernando earthquake (Langston, 1978); 1966 El Golfo earthquake (Ebel et al., 1978); 1969 New Hebrides earthquake sequence (Ebel, 1977); 1967 Caracas earthquake (Rial, 1978); 1973 Hawaiian earthquake (Butler, 1979); 1976 Tangshan China earthquake sequence (Butler et al., 1979).

This paper shall be concerned with an application of two of the above mentioned source studies to the problem of obtaining SS travel times.

\section{REviEW OF SS}

$S S$ is a shear wave which reflects once off the Earth's free surface at the midpoint of its propagation. The nature of the propagation, however, is such that the wave interacts with an internal caustic and is phase shifted. At sufficiently high frequencies, Jeffreys and Lapwood (1957) have shown that the distortion incurred is manifested as a constant $\pi / 2$ phase shift in each frequency.

The behavior of the high-frequency asymptote has been treated by a body of acoustic literature (Arons and Tennie, 1950; Tolstoy, 1968; Sachs and Silbiger, 1971;

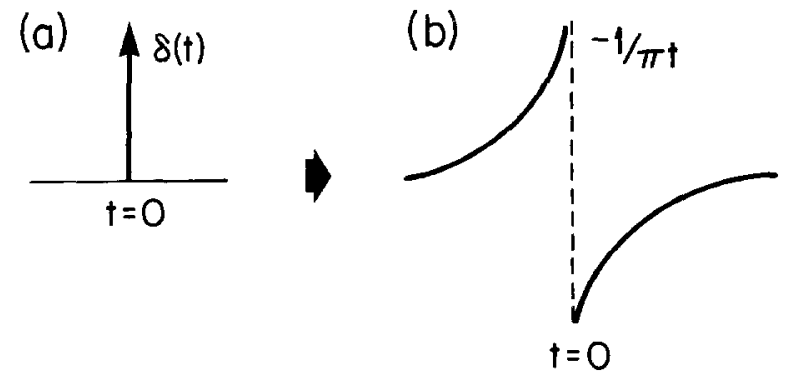

FIG. 1. (a) Delta function arriving at time $t=0$. (b) The Hilbert transform of $\delta(t),(-1 / \pi t)$. Note that the energy arrives before the ray arrival time (adapted from Choy and Richards, 1975).

Blatstein, 1971). Hill (1974) has shown for an analytic velocity model that to maintain causality, the phase shift at low frequencies must go to zero. Helmberger (1973) attempted to model PP using a coarsely layered, but more realistic earth model by the generalized ray method.

In an observational vein, Choy and Richards (1975) demonstrated qualitatively that the pulse distortion of $S S$ was well approximated by a constant $\pi / 2$ phase shift. Applying a frequency independent $\pi / 2$ phase shift is equivalent to the Hilbert transformation of a function to its allied function. It was found that the comparison of the waveforms of $S S$ and Hilbert transformed $S$ for several events was quite favorable. Some research has been conducted using the phase SS to extract travel times (Brune, 1964), torsional overtone dispersion (Brune and Gilbert, 1974), and shear attenuation (Brune, 1977). However, as these studies neglected distortional propagation effects due to the caustic, their results may have to be reevaluated.

The effect of Hilbert transformation is illustrated in Figure 1 with a delta function. It is easily seen that obtaining a geometric ray arrival time for a phase distorted in this manner would be quite difficult by conventional visual picking methods. As an additional check to the justification of using a Hilbert transform to mimic the effect of the caustic, several $S$ and $S S$ waves were sought for the following fortuitous geometry. Stations were chosen for events for which $S$ and $S S$ leave the source at the same ray parameter and azimuth; that is, the station recording $S S$ is twice the 
distance of the station recording $S$. In this way, the $S$ wave is nearly the input to $S S$ before the distortion at the caustic. Three of these event-station pairs are shown in Figure 2. The middle trace for each event was produced by performing a Hilbert transformation upon the $S$ wave (top trace), as suggested by Choy and Richards (1975). As $S S$ suffers twice the attenuation of $S$, a Futterman $Q$ operator with $t^{*}=$ 4 was also applied to the middle trace. The fit between the synthetically produced $S S$ and the observed is quite good-an important point since the phase distortion at the caustic is theoretically asymptotic to a constant $\pi / 2$ only at high frequencies.

\section{Traver Times}

As we have seen from Figures 1 and 2, it is difficult, if not impossible, to pick the conventional geometric arrival time of a distorted phase such as SS by visual onset

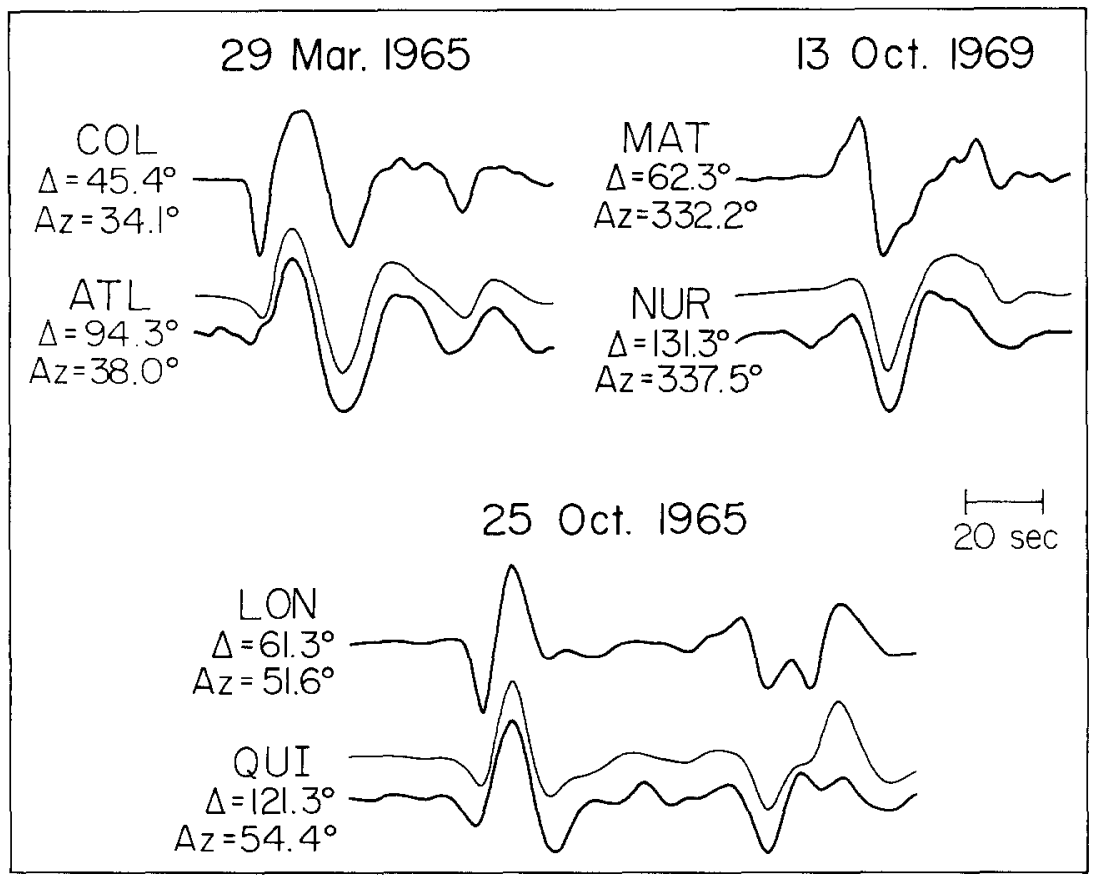

FIG. 2. Recordings of $S$ and $S S$ for three earthquakes where the station recording SS (lower trace) is roughly twice the distance from the source and at nearly the same azimuth as the station recording direct $S$ (upper trace). The center trace for each event illustrates the effect of applying a Hilbert transform to the $S$ wave (upper trace) to imitate the effect of the $S S$ caustic.

methods. To overcome this difficulty, a waveform correlation method was utilized to determine travel times of $S S$.

All SS waves recorded by stations of the WWSSN for the 1968 Borrego Mountain earthquake and 1973 Hawaiian earthquake were collected, digitized, and rotated into $S H$ and $S V$ components of motion. The source-time functions for these two events are well-constrained by the waveform source studies of, respectively, Burdick and Mellman (1976), and Butler (1979). Synthetic SS waves are then generated using these mechanisms in the following manner. The ray parameter of $S S$ for a particular station is the same as the ray parameter of $S$ for a virtual station at half the distance to the source. Synthetic $S$ waves are computed using the appropriate ray parameter and azimuth. The effect of the caustic of SS is mimicked by Hilbert transformation of the $S$ wave to its allied function. The arrival time on the original 
$S$-wave synthetic is used as the reference visual onset time. To include attenuation, the synthetics were convolved with a Futterman (1962) $Q$ operator. Values of $t_{\beta}{ }^{*}$ between 8 and 10 were chosen to include nearly the range of uncertainty associated with the phase. Since the effect of errors of in $t^{*}$ become more pronounced later in the waveform, only the initial major swing of the $S S$ wave is used in the correlation procedure. A visual inspection of the overall likeness of the synthetic and observed waveforms is made in judging the quality of each observation. In the actual timing determination, it is possible to define not only the best correlation and hence the best estimate of the travel time, but also the total range of acceptable correlation. Thus, the precision of the travel time may be accurately estimated. The overall intent of the timing procedure is to produce as nearly as possible an onset time for $S S$ that can be easily compared to previous $S$ studies based on conventional visual timing methods.

TABLE 1

Source Parameters for the Borrego Mountain and Hawail

EARTHQUAKES

Borrego Mountain

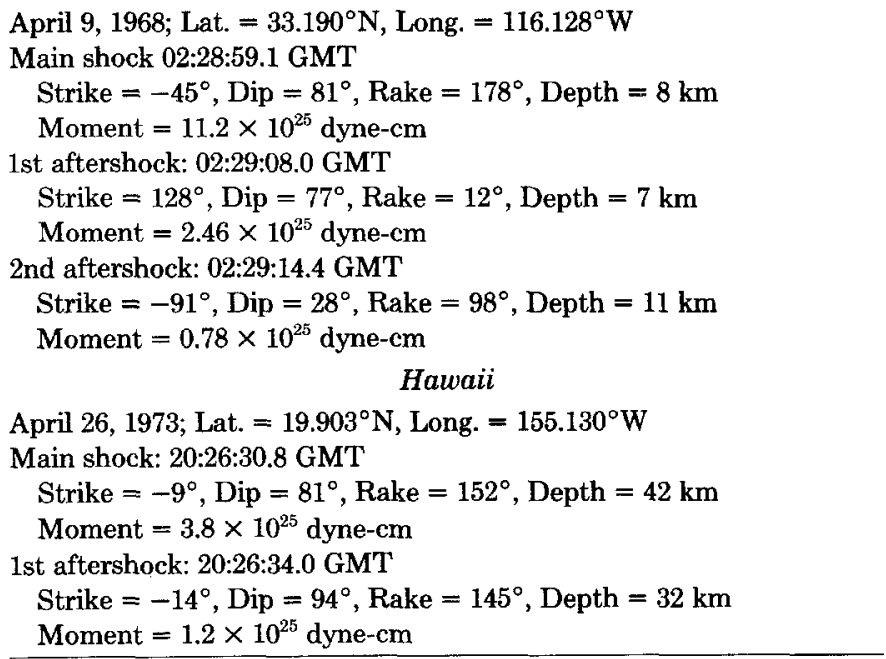

The application of this waveform correlation method has been applied to $S$ waves by Hart and Butler (1978) to the same earthquakes used in this study. The Borrego Mountain, California earthquake was a magnitude 6.4 strike-slip event which occurred on April 9, 1968 at 02:28:59.1 GMT (Allen and Nordquist, 1972). The error of the epicentral location is estimated to be within $3 \mathrm{~km}$ (Allen and Nordquist). The depth estimate of $11 \mathrm{~km}$ was confirmed by Burdick and Mellman (1976).

Within these limits the effects of origin time and hypocentral errors on seismic travel times are bound by instrument timing accuracy. In 1968, the accuracy was 0.4 to 0.5 sec or better. Burdick and Mellman (1976) demonstrated that the Borrego earthquake was actually a multiple event consisting of a main shock and two aftershocks. The source parameters describing these three events are given in Table 1. As the Borrego event was shallow, the observed shear waves are actually the combination of $S$ and $s S$, and thus the $S S$ synthetics were constructed to include both the direct ray and the near-source, surface reflection.

The Hawaiian earthquake occurred on April 26, 1973 at 20:26:30.8 GM'T northeast 
of the city of Hilo at a depth of $42 \mathrm{~km}$. The local control for this event is good, though not to the degree of the Borrego Mountain earthquake. The problem with the Hawaiian earthquake is that the epicenter lies just off the coast and thus slightly outside the local seismic network. The source mechanism of this event (Butler, 1979) is one of a double event with both shocks having similar mechanisms. The source parameters are given in Table 1 . As the depth of the event as determined by the teleseismic waveform analysis agrees well with the local determination, the

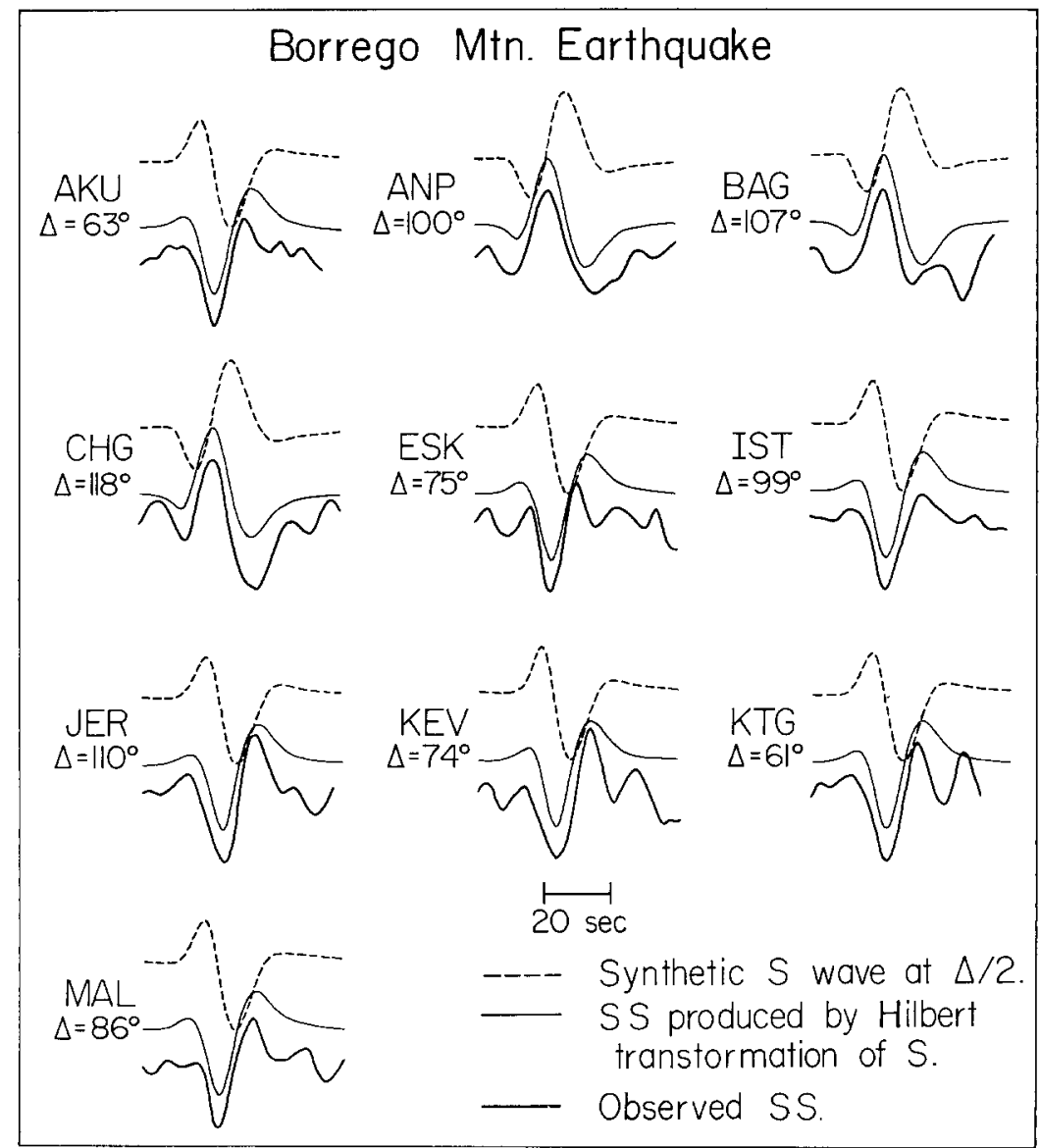

FIG. 3. A comparison between observed SS from the Borrego Mountain earthquake and synthetic SS. The synthetics were generated using the source-time function of Burdick and Mellman (1976) and corrected for the SS caustic by Hilbert transformation.

overall accuracy to which travel times may be trusted is to within 2 sec. As the near source, surface reflected shear energy arrives nearly $15 \mathrm{sec}$ after the direct arrivals for these depths, only the direct ray is included in the synthetics.

The Borrego Mountain data set yielded 26 high-quality transverse SS, or SHSH, observations; the Hawaiian data set yielded 12 SHSH observations. These highquality observations were then carefully redigitized twice and averaged together to minimize errors. The lesser number of high-quality Hawaiian observations is due to an azimuthal near-source travel-time anomaly, reported by Hart and Butler (1978), presumably indicating a near-source, laterally varying structure. This anomaly lends greater uncertainty to any $S S$ time for the Hawaiian event. The $S$-waveform 
observations, however, are well matched by synthetics generated for the source model. The 12 SS observations from the Hawaiian earthquake were modeled primarily as an additional test to see how well synthetic $S S$ can match observed waveforms. In a treatment of $S V S V$ for both events, it was found that none of the synthetics satisfactorily matched the observations. $S V$ is notoriously known to exhibit greater complexity than $S H S H$. These complexities may be attributed in part to $P-S V$ conversions at the source, midpoint reflection, and receiver and in part to interference with $S V$ coupled $P L$ waves.

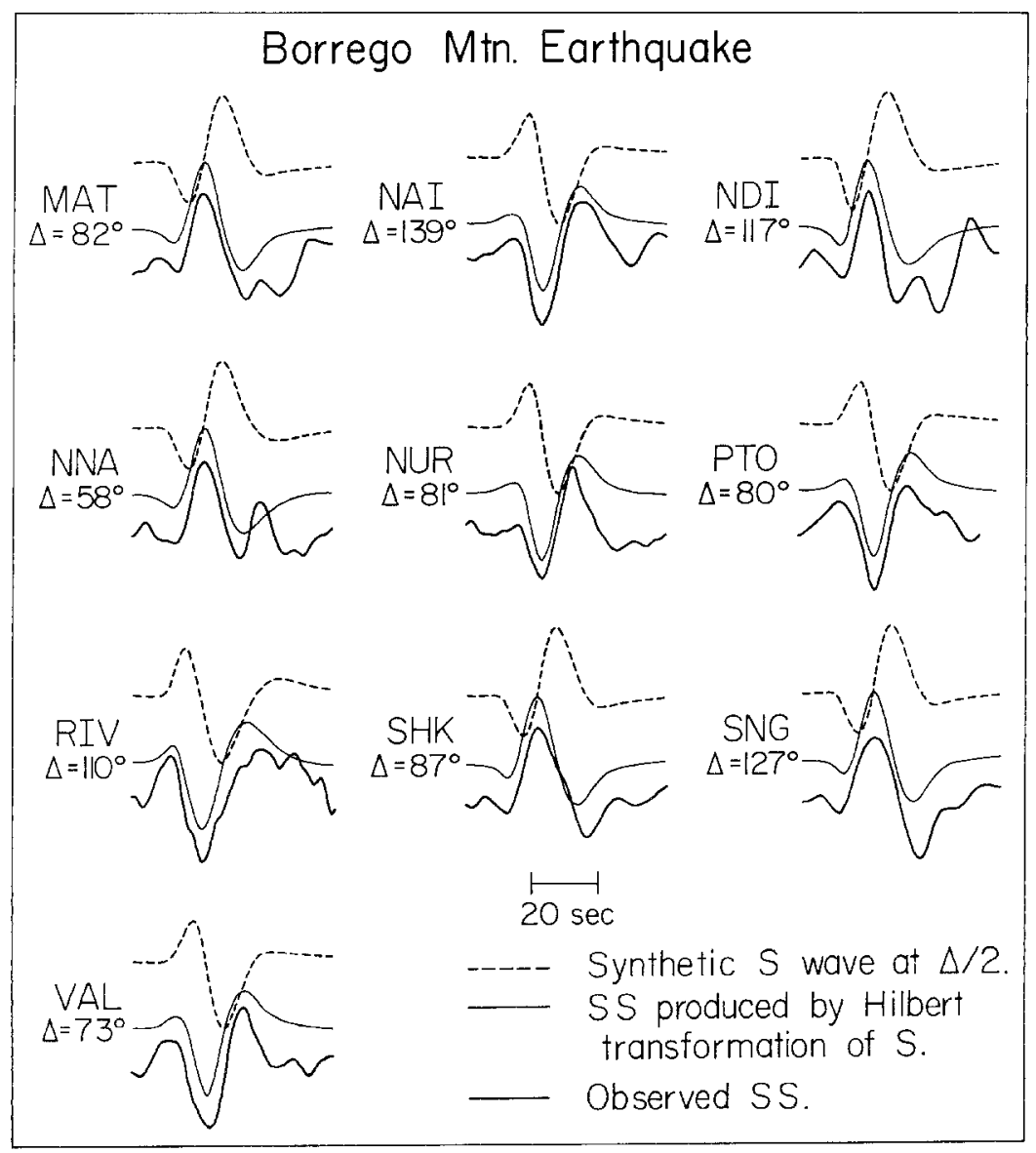

FIG. 4. A comparison between observed SS from the Borrego Mountain earthquake and synthetic SS. The synthetics were generated using the source-time function of Burdick and Mellman (1976) and corrected for the $S S$ caustic by Hilbert transformation.

The comparison between SS observations and synthetics is illustrated in Figures 3 and 4 for the Borrego Mountain earthquake, and in Figure 5 for the Hawaiian earthquake. The upper trace for each station shows the synthetic $S$ wave generated for the appropriate source-time function. An $S S$ wave is produced by Hilbert transformation of the $S$ wave to yield the middle traces. The match between the synthetic and observed $S S$ is quite good in all cases, affording us a large measure of confidence in the method. The quality of the fits also indicates considerable potential in using $S S$ for additional constraints in waveform studies of earthquake source mechanisms. As $S S$ observations are available for twice the range of $S$ waves, $S S$ 
may be very useful in source studies hindered by azimuthal gaps in station coverage due to the oceans.

In anticipation of questions to be raised in the "Discussion" section, tests were conducted to determine the importance of midpoint reflection and receiver structure. To accomplish this, several crust-to-mantle transition models were tried by computing the transfer function for the layered stack by Haskell propagator matrices (Haskell, 1953; Harkrider, 1964; Fuchs, 1966). These transfer functions were then convolved with the synthetic $S S$. The effect of a $6.5 \mathrm{~km} / \mathrm{sec}, 33 \mathrm{~km}$ thick crust over

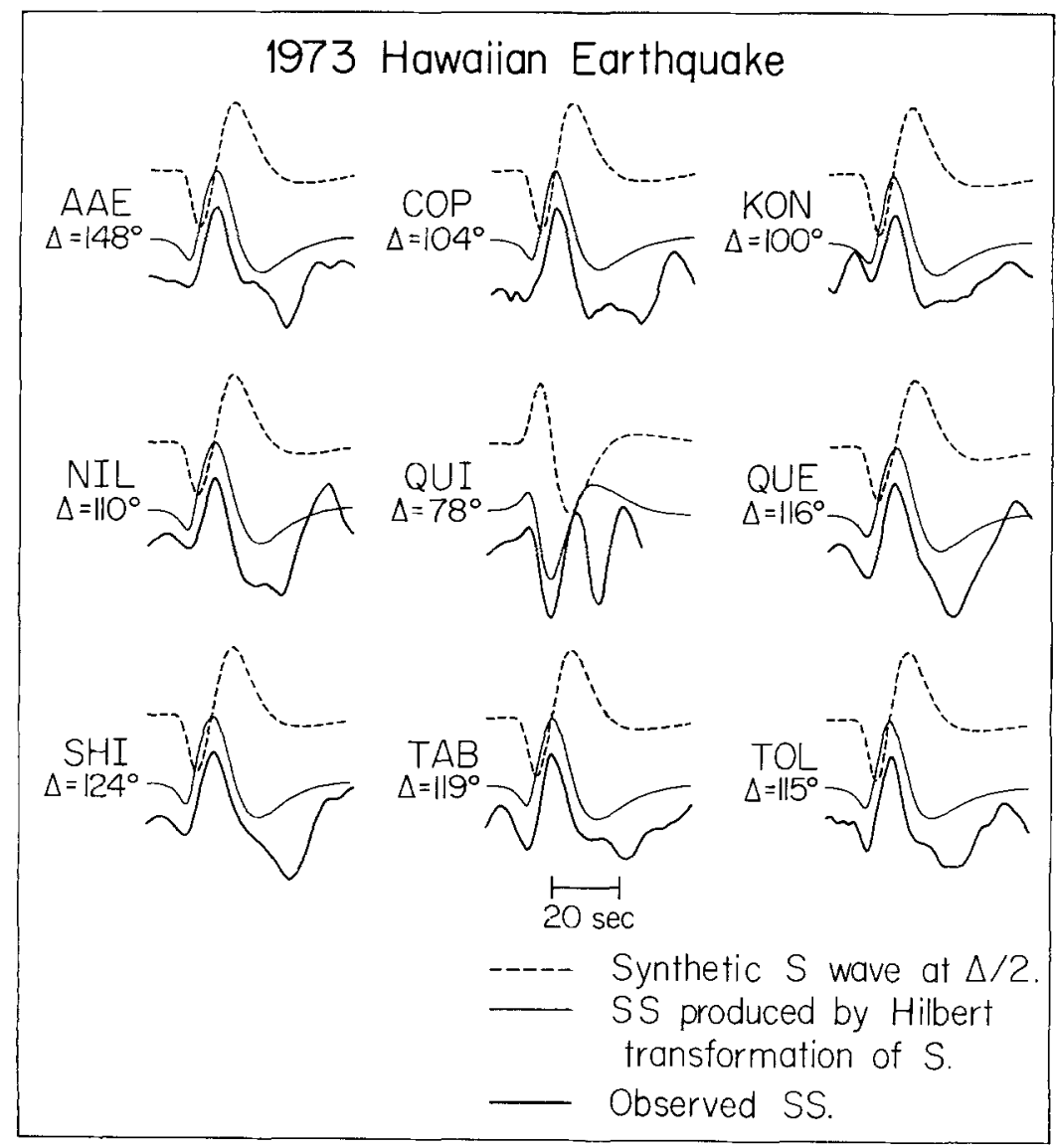

FIG. 5. A comparison between observed SS from the 1973 Hawainan earthquake and synthetic SS. The synthetic $S S$ phases were generated using the source-time function of Butler (1978) and corrected for the caustic by Hilbert transformation.

an $8.0 \mathrm{~km} / \mathrm{sec}$ mantle is small due to the low amplitude and time separation of the precursors and reverberations. Large mid-crustal discontinuities can produce distortion effects. However, crustal sections for the midpoint reflections of SS used in this study are not known in sufficient detail to justify any corrections of this nature. The only exception to this is for the $S S$ recorded at JER from the Borrego Mountain earthquake. The midpoint reflection for this path lies in the middle of the Greenland icecap, whose thickness is nearly $3 \mathrm{~km}$. In generating the synthetic $S S$ for JER, the crust-ice reflection and ice reverberations are included.

Tables 2 and 3 list SS travel times for the Borrego Mountain and Hawaiian earthquakes, respectively. The distance and azimuth of the station, coordinates of 
TABLE 2

SS Travel-Time Residuals From Borrego Mountain

\begin{tabular}{|c|c|c|c|c|c|c|}
\hline \multirow{2}{*}{ Station } & \multirow{2}{*}{ Delta } & \multirow{2}{*}{ Azimuth } & \multicolumn{2}{|c|}{ Reflection Point } & \multirow{2}{*}{$\begin{array}{l}\mathrm{T}-\mathrm{T}_{\mathrm{JB}} \\
(\mathrm{sec})\end{array}$} & \multirow{2}{*}{$\begin{array}{l}\text { Error } \\
\text { (sec.) }\end{array}$} \\
\hline & & & Lat. & Long. & & \\
\hline AKU & 63.42 & 27.3 & $58.95^{\circ} \mathrm{N}$ & $88.41^{\circ} \mathrm{W}$ & +5.0 & $\begin{array}{l}+0.8 \\
-0.8\end{array}$ \\
\hline ANP & 100.14 & 309.0 & $49.16^{\circ} \mathrm{N}$ & $178.66^{\circ} \mathrm{E}$ & +5.1 & $\begin{array}{l}+1.5 \\
-0.8\end{array}$ \\
\hline $\mathrm{BAG}$ & 106.79 & 303.1 & $44.02^{\circ} \mathrm{N}$ & $175.09^{\circ} \mathrm{E}$ & +3.1 & $\begin{array}{l}+1.0 \\
-0.6\end{array}$ \\
\hline $\mathrm{CHG}$ & 118.39 & 321.7 & $57.77^{\circ} \mathrm{N}$ & $160.53^{\circ} \mathrm{E}$ & +7.5 & $\begin{array}{l}+1.4 \\
-1.4\end{array}$ \\
\hline ESK & 74.91 & 33.0 & $59.51^{\circ} \mathrm{N}$ & $75.62^{\circ} \mathrm{W}$ & -4.3 & $\begin{array}{l}+0.9 \\
-1.6\end{array}$ \\
\hline JER & 109.96 & 25.8 & $68.71^{\circ} \mathrm{N}$ & $38.69^{\circ} \mathrm{E}$ & +8.8 & $\begin{array}{l}+1.1 \\
-1.3\end{array}$ \\
\hline IST & 99.45 & 26.0 & $68.14^{\circ} \mathrm{N}$ & $32.85^{\circ} \mathrm{E}$ & +4.9 & $\begin{array}{l}+0.8 \\
-0.6\end{array}$ \\
\hline $\mathrm{KEV}$ & 73.91 & 12.6 & $68.16^{\circ} \mathrm{N}$ & $95.61^{\circ} \mathrm{W}$ & +1.1 & $\begin{array}{l}+1.9 \\
-1.9\end{array}$ \\
\hline KTG & 60.50 & 22.7 & $59.53^{\circ} \mathrm{N}$ & $93.70^{\circ} \mathrm{W}$ & +1.7 & $\begin{array}{l}+0.9 \\
-0.6\end{array}$ \\
\hline MAL & 85.70 & 48.5 & $51.21^{\circ} \mathrm{N}$ & $62.06^{\circ} \mathrm{W}$ & +0.3 & $\begin{array}{l}+0.9 \\
-0.9\end{array}$ \\
\hline MAT & 81.92 & 308.4 & $49.01^{\circ} \mathrm{N}$ & $166.94^{\circ} \mathrm{W}$ & +4.8 & $\begin{array}{l}+0.8 \\
-0.9\end{array}$ \\
\hline NAI & 139.33 & 44.3 & $48.96^{\circ} \mathrm{N}$ & $19.66^{\circ} \mathrm{W}$ & +10.6 & $\begin{array}{l}+0.9 \\
-0.8\end{array}$ \\
\hline NDI & 117.19 & 346.8 & $78.80^{\circ} \mathrm{N}$ & $149.22^{\circ} \mathrm{E}$ & +4.9 & $\begin{array}{l}+1.0 \\
-0.5\end{array}$ \\
\hline NNA & 58.49 & 133.4 & $11.26^{\circ} \mathrm{N}$ & $94.92^{\circ} \mathrm{W}$ & +11.2 & $\begin{array}{l}+0.5 \\
-0.7\end{array}$ \\
\hline NUR & 81.26 & 18.5 & $68.77^{\circ} \mathrm{N}$ & $81.56^{\circ} \mathrm{W}$ & +1.4 & $\begin{array}{l}+0.8 \\
-0.7\end{array}$ \\
\hline PTO & 80.43 & 46.9 & $52.00^{\circ} \mathrm{N}$ & $66.44^{\circ} \mathrm{W}$ & -3.1 & $\begin{array}{l}+1.1 \\
-0.5\end{array}$ \\
\hline RIV & 109.57 & 241.9 & $0.48^{\circ} \mathrm{S}$ & $162.24^{\circ} \mathrm{W}$ & +8.5 & $\begin{array}{l}+1.0 \\
-1.0\end{array}$ \\
\hline SHK & 86.73 & 309.5 & $49.86^{\circ} \mathrm{N}$ & $171.08^{\circ} \mathrm{W}$ & +6.8 & $\begin{array}{l}+0.9 \\
-0.8\end{array}$ \\
\hline SNG & 126.81 & 312.1 & $48.49^{\circ} \mathrm{N}$ & $158.07^{\circ} \mathrm{E}$ & +10.3 & $\begin{array}{l}+1.0 \\
-1.0\end{array}$ \\
\hline VAL & 73.40 & 38.4 & $56.23^{\circ} \mathrm{N}$ & $74.46^{\circ} \mathrm{W}$ & -7.6 & $\begin{array}{l}+1.8 \\
-1.8 \\
\end{array}$ \\
\hline
\end{tabular}

the midpoint reflection, and the precision of each measurement are included. The times have been corrected for surface elevation of the receiver and midpoint reflection, and the ellipticity at the source, midpoint reflection, and receiver. The Borrego data have been corrected to a surface focus; the Hawaiian data to $33 \mathrm{~km}$ depth. No station corrections have been applied to the data. As discussed above, the Borrego Mountain times are accurate to within $0.5 \mathrm{sec}$. In Figure 6 the Borrego data are plotted in an azimuthal equal-distance projection centered at the epicenter. Hart and Butler (1978) found large azimuthal source anomalies associated with the Hawaiian $S$ data, presumably due tö lateral heterogeneity. As the interpretation of $S S$ travel times from Hawaii suffer the same complications, only the Borrego data will be discussed.

Differential $S S-S$ times are shown in Table 4 for stations whose $S$ times were 
TABLE 3

\begin{tabular}{|c|c|c|c|c|c|c|}
\hline \multirow{2}{*}{ Station } & \multirow{2}{*}{ Delta } & & \multicolumn{2}{|c|}{ Reflection Point } & \multirow{2}{*}{ T-T TA $_{\text {B }}(\mathrm{sec})}$. & \multirow{2}{*}{$\begin{array}{l}\text { Error } \\
\text { (sec.) }\end{array}$} \\
\hline & & Azimuth & Lat. & Long. & & \\
\hline $\mathrm{AAE}$ & 148.16 & 333.3 & $64.47^{\circ} \mathrm{N}$ & $110.55^{\circ} \mathrm{E}$ & +4.6 & $\begin{array}{l}+1.0 \\
-0.8\end{array}$ \\
\hline $\mathrm{COP}$ & 103.99 & 7.2 & $70.85^{\circ} \mathrm{N}$ & $137.71^{\circ} \mathrm{W}$ & +4.4 & $\begin{array}{r}+0.9 \\
-1.3\end{array}$ \\
\hline KON & 99.77 & 7.8 & $68.73^{\circ} \mathrm{N}$ & $138.61^{\circ} \mathrm{W}$ & +6.7 & $\begin{array}{l}+0.8 \\
-0.9\end{array}$ \\
\hline NIL & 109.56 & 318.6 & $50.71^{\circ} \mathrm{N}$ & $146.70^{\circ} \mathrm{E}$ & +6.1 & $\begin{array}{r}+1.6 \\
-1.1\end{array}$ \\
\hline QUE & 115.82 & 319.9 & $52.33^{\circ} \mathrm{N}$ & $142.08^{\circ} \mathrm{E}$ & +4.5 & $\begin{array}{l}+1.1 \\
-1.1\end{array}$ \\
\hline QUI & 77.50 & 94.8 & $12.48^{\circ} \mathrm{N}$ & $115.44^{\circ} \mathrm{W}$ & +10.6 & $\begin{array}{l}+0.5 \\
-1.1\end{array}$ \\
\hline SHI & 124.02 & 330.8 & $62.31^{\circ} \mathrm{N}$ & $137.63^{\circ} \mathrm{E}$ & +3.9 & $\begin{array}{l}+1.0 \\
-1.0\end{array}$ \\
\hline TAB & 118.92 & 340.7 & $69.66^{\circ} \mathrm{N}$ & $150.37^{\circ} \mathrm{E}$ & +8.4 & $\begin{array}{l}+0.9 \\
-0.9\end{array}$ \\
\hline TOL & 114.70 & 24.2 & $65.00^{\circ} \mathrm{N}$ & $100.80^{\circ} \mathrm{W}$ & +0.3 & $\begin{array}{l}+0.8 \\
-0.8\end{array}$ \\
\hline
\end{tabular}

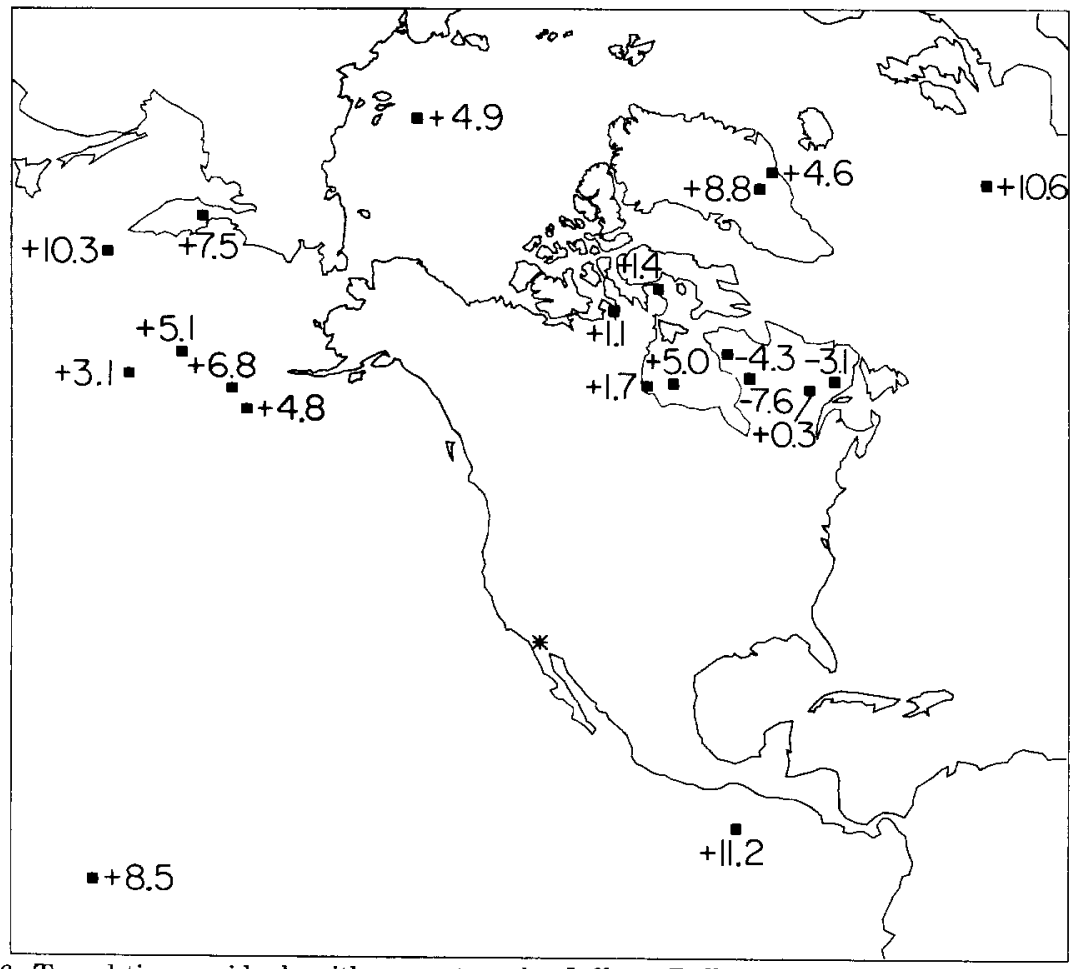

FIG. 6. Travel-time residuals with respect to the Jeffreys-Bullen times (positive $=$ late) of $S S$ from the 1968 Borrego Mountain earthquake (asterisk). The square indicates the midpoint of the propagation path where the phase reflects off the Earth's free surface.

previously measured by Hart and Butler (1978). These differential times are plotted in Figure 7 in an azimuthal equal-distance projection centered on the Borrego epicenter. The lower center $\mathrm{JB}$ residual is a differential time from the Hawaiian earthquake for station QUI. 
No station corrections were applied to the absolute SS times. This choice was made for a number of reasons. $S$-station anomalies determined by different studies are at times significantly inconsistent (Doyle and Hales, 1967; Hales and Roberts, 1970; Sengupta, 1975). The quality of the corrections themselves is not homogeneous. Many are based on relatively few measurements. The standard deviations of the corrections often do not preclude a no correction value. No azimuthal dependence was included in the above $S$ studies, whereas $P$ corrections (Bolt and Nuttli, 1966) and $S-P$ corrections (Uhrhammer, 1977) have been shown to exhibit significant azimuthal variations. A comparison was made between the $S S-S$ differential times

TABLE 4

\begin{tabular}{|c|c|c|c|c|c|c|}
\hline \multirow{3}{*}{$\frac{\text { Station }}{\text { AKU }}$} & \multicolumn{2}{|c|}{$\begin{array}{c}S \text { Wave* } \\
\left(\mathrm{T}-\mathrm{T}_{\mathrm{IB}} \text { Error }\right)\end{array}$} & \multicolumn{2}{|c|}{$\begin{array}{c}\text { SS Wave } \\
\text { (T-T } \text { JB Error) }^{-}\end{array}$} & \multicolumn{2}{|c|}{$\begin{array}{c}\text { SS-S } \\
(\mathrm{T}-\mathrm{T} \cdot \mathrm{IB} \text { Error) } \\
\end{array}$} \\
\hline & +9.2 & +0.5 & +5.0 & +0.8 & -4.2 & +1.3 \\
\hline & & -0.5 & & -0.8 & & -1.3 \\
\hline \multirow[t]{2}{*}{ ESK } & +5.0 & +0.6 & -4.3 & +0.9 & -9.3 & +1.3 \\
\hline & & -0.3 & & -1.6 & & -2.6 \\
\hline \multirow[t]{2}{*}{ KEV } & +3.6 & +0.5 & +1.1 & +1.9 & -2.5 & +2.5 \\
\hline & & -0.6 & & -1.9 & & -2.4 \\
\hline \multirow[t]{2}{*}{ KTG } & +5.8 & +0.7 & +1.7 & +0.9 & -4.1 & +1.2 \\
\hline & & -0.3 & & -0.6 & & -1.3 \\
\hline \multirow[t]{2}{*}{ MAL } & +4.9 & +0.7 & +0.3 & +0.9 & -4.6 & +1.4 \\
\hline & & -0.5 & & -0.9 & & -1.6 \\
\hline \multirow[t]{2}{*}{ NNA } & +6.7 & +0.5 & +11.2 & +0.5 & +4.5 & +1.3 \\
\hline & & -0.8 & & -0.5 & & -1.0 \\
\hline \multirow[t]{2}{*}{ NUR } & +5.2 & +0.3 & +1.4 & +0.8 & -3.8 & +1.5 \\
\hline & & -0.7 & & -0.7 & & -1.0 \\
\hline \multirow[t]{2}{*}{ PTO } & +4.8 & +0.5 & -3.1 & +1.1 & -7.9 & -1.8 \\
\hline & & -0.7 & & -0.5 & & -1.0 \\
\hline \multirow[t]{2}{*}{ SHK } & +4.0 & +0.5 & +6.8 & +0.9 & +2.8 & +1.4 \\
\hline & & -0.5 & & -0.8 & & -1.3 \\
\hline \multirow[t]{2}{*}{ VAL } & +4.2 & +0.5 & -7.6 & +1.8 & -11.8 & +2.4 \\
\hline & & -0.6 & & -1.8 & & -2.3 \\
\hline \multirow[t]{2}{*}{ QUI† } & +8.0 & +0.5 & +10.6 & +0.5 & +2.6 & +0.8 \\
\hline & & -0.3 & & -1.1 & & -1.6 \\
\hline
\end{tabular}

* Hart and Butler (1978).

$\dagger$ From 1973 Hawaiian earthquake.

and absolute SS times, with and without station corrections. Station corrections were found to degrade more often than improve agreement. Although a blanket application of station corrections to the absolute $S S$ travel times does not seem to be desired, a knowledge of possible corrections is useful in judging individual $S S$ travel-time anomalies. For this reason, a list of station corrections from Sengupta (1975) is included in Table 5.

\section{Discussion}

The Borrego data in Figure 6 show remarkable range in the J-B residuals-from $7.6 \mathrm{sec}$ fast in the Canadian shield to $11.2 \mathrm{sec}$ slow in the Guatemalan Basin. In this figure it is more important to consider the variation of the residuals in a relative sense as opposed to each individual measurement. Hart and Butler (1978) found that the baseline of the $S$-wave travel times for Borrego was 6 sec late with respect to J-B. Thus, even though the Borrego times are accurate in an absolute sense to 
within $0.5 \mathrm{sec}$, the source region has associated with it a 6 -sec slow, travel-time anomaly. As there is no apparent azimuthal trend in the anomaly (Hart and Butler, 1978), an approximate source correction of $6 \mathrm{sec}$ will be automatically applied in the discussion of these points. The differential times presented in Figure 7 are naturally free of this anomalous effect in the source region, and also anomalies at the receivers. All travel times are discussed relative to the Jeffreys-Bullen tables (1940). Source corrected absolute times were compared to differential times at common stations. The average agreement of the two timing methods was within 1.2 sec. Table 6 lists a brief description of the reflection points for the data in Figures 6 and 7.

Two-way SS reflections in the north Pacific and southwest of Hawaii scatter at

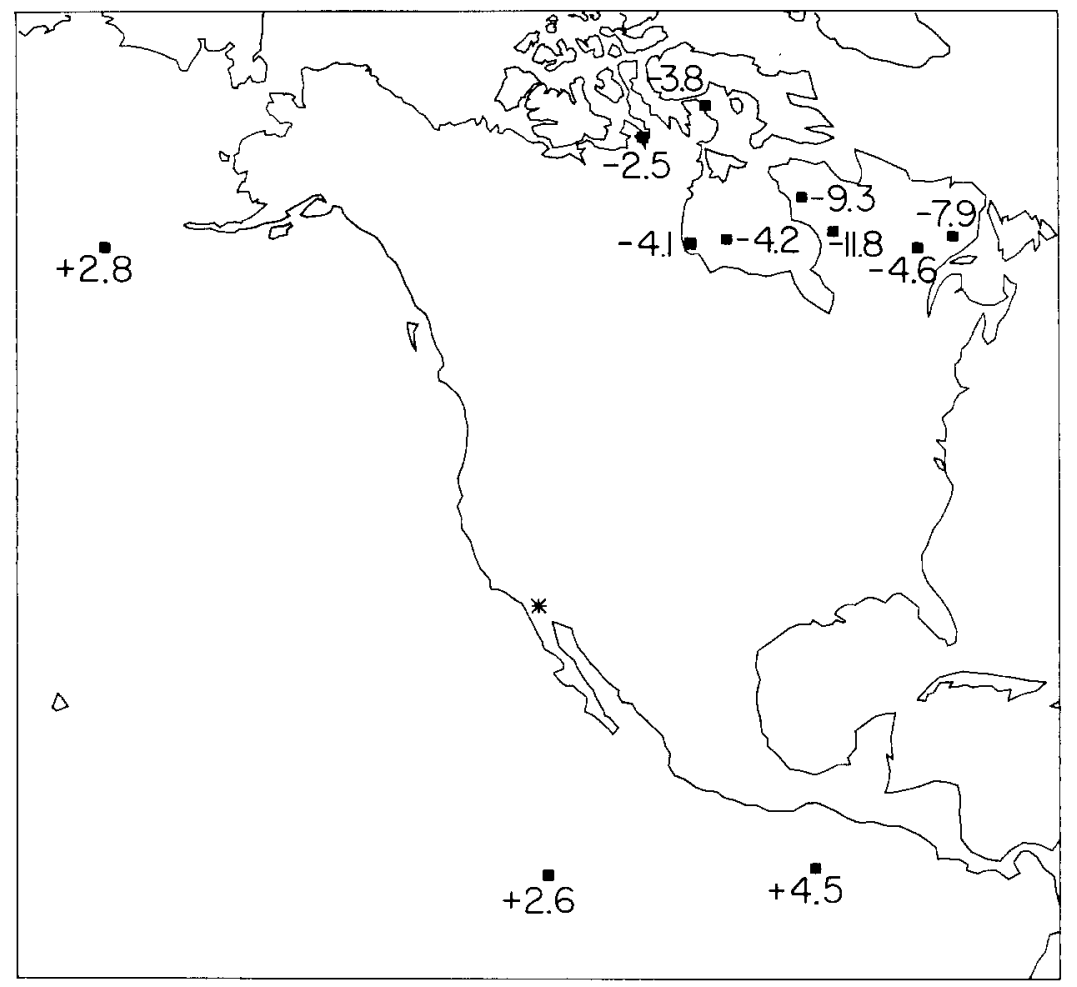

FIG. 7. Differential travel-time residuals (with respect to the Jeffreys-Bullen times; positive $=$ late) for SS-S from the 1968 Borrego Mountain earthquake (asterisk). The squares indicate the midpoints of the propagation paths where the phase reflects off the Earth's free surface. The +2.6 sec differential travel-time residual on the lower center is from the 1973 Hawaiian earthquake.

roughly $\pm 2.7 \mathrm{sec}$ around $\mathrm{J}-\mathrm{B}$ values. The reflection in the north Atlantic is $4.6 \mathrm{sec}$ slower than J-B, but a correction for the receiver, NAI, may be in order. Station NAI-Nairobi, Kenya-lies along the East African rift zone and shows a +5.7 station anomaly in Table 5 (from Sengupta, 1975). This correction brings the value, -1.1 sec, in agreement with the Pacific data. The reflection at the edge of the Siberian continental shelf in the Arctic Ocean for a receiver at NDI on the Indian shield is $1.1 \mathrm{sec}$ fast. A station correction of $-3.5 \mathrm{sec}$ decreases this value to $+2.4 \mathrm{sec}$ slow relative to J-B. The two reflections at the Kurile-Kamchatka subduction zone are +1.5 and +4.6 sec slow.

The source corrected residuals of SS recorded at JER $(+2.8 \mathrm{sec})$ and IST $(-1.4)$ which reflect at Greenland are comparable to the oceanic values. Although the 
geology of Greenland beneath the ice cap is not known, the exposed edges are Precambrian shield. The $S S$ residuals reflecting beneath the Canadian shield are, contrastingly, quite fast. The differential $S S-S$ times in Figure 7 range from 2.5 to $11.8 \mathrm{sec}$ faster than J-B. The extremely slow times for the Greenland shield cannot be explained by a receiver anomaly, as the station corrections for JER and IST from Sengupta (1975) in Table 5 are fast with respect to the average earth.

The source corrected absolute SS times for oceanic reflections, whether or not station corrections are applied, average at the $\mathrm{J}$-B baseline. The three differential $S S-S$ times in Figure 7 reflecting beneath the Pacific average $3.3 \mathrm{sec}$ slower than JB. The reflections in the Pacific do not substantially correlate with the age of the

TABLE 5

Station Anomaly for $S$ Travel Times (Sengupta,

\begin{tabular}{lrrr}
\multicolumn{3}{c}{$1975)$} & \\
\hline Station & Value* & S.D. & $N$ \\
\hline AAE & 5.88 & 2.82 & 4 \\
ANP & -0.66 & 4.09 & 12 \\
BAG & 0.37 & 2.47 & 13 \\
CHG & -1.07 & 2.07 & 13 \\
COP & -3.06 & 3.11 & 8 \\
ESK & -1.71 & 2.06 & 13 \\
JER & -2.63 & 4.00 & 7 \\
IST & -4.04 & 3.99 & 3 \\
KEV & -3.90 & 1.65 & 7 \\
KON & -2.29 & 1.12 & 8 \\
KTG & -0.63 & 1.86 & 4 \\
MAL & -0.93 & 1.93 & 5 \\
NAI & 5.67 & 3.21 & 7 \\
NDI & -3.47 & 1.99 & 15 \\
NIL & -1.80 & 0.42 & 2 \\
NNA & 3.20 & 4.33 & 4 \\
NUR & -4.36 & 1.26 & 8 \\
PTO & 0.17 & 2.84 & 10 \\
QUE & -1.30 & 2.37 & 10 \\
QUI & 1.00 & 0.00 & 1 \\
RIV & 1.94 & 1.76 & 12 \\
SHI & -3.24 & 0.92 & 9 \\
SHK & 0.34 & 2.57 & 4 \\
TAB & -0.79 & 2.36 & 6 \\
TOL & 4.43 & 0.81 & 5 \\
VAI & -1.37 & 1.12 & 7 \\
\hline Negati & & & \\
\hline
\end{tabular}

* Negative is fast.

oceanic lithosphere. The data in the north Pacific, $\sim 70$ m.y., range between -3.3 to $+2.8 \mathrm{sec}$. The datum in the $100 \mathrm{~m}$.y. central Pacific is $2.5 \mathrm{sec}$ slower than J-B. The slowest time, $+4.5 \mathrm{sec}$, lies on $40 \mathrm{~m}$.y. old crust, while the +2.6 -sec residual reflects beneath 10 to 25 m.y. old lithosphere.

The largest shear anomaly in the data set is not an SS time, but rather is the 6sec slow anomaly of the Borrego source (Hart and Butler, 1978). This is equivalent to a +12 -sec SS residual and is significantly slower than any of the SS differential or source corrected absolute times. The Borrego epicenter is located at the western edge of the Salton Trough in southern California. This is a region of high heat flow, geothermal activity, gravity variations and extensional tectonics, and is viewed as a continental continuation of the active spreading center in the Gulf of California. Duschenes and Solomon (1977) have measured shear-wave residuals from ridge 
crest and intraplate oceanic earthquakes. When plotted as a function of age these (one-way) residuals show a $6 \pm 1$ sec decrease from ridge crest to lithosphere 100 m.y. old. As the origin times of these events are determined by $P$ waves and thus implicitly contain $P$ delay information, the true $S$ decrease with age may be a second or so greater. The Borrego earthquake shear anomaly is approximately $6 \pm 1.5 \mathrm{sec}$ slower than one-way $S S$ residuals for reflections beneath the $\sim 70 \mathrm{~m}$.y. old north Pacific, and is consistent with the oceanic $S$ delay versus age variation of Duschenes and Solomon (1977) between the ridgecrest and $70 \mathrm{~m} . \mathrm{y}$. old lithosphere. This agreement indicates that the average shear velocity beneath the Salton Trough in southern California is comparable to average shear velocities at mid-ocean ridge spreading centers.

TABLE 6

Description Reflection Points for Figures 6 and 7

\begin{tabular}{|c|c|c|c|}
\hline Station & $\begin{array}{c}\text { SS T-T, } \\
\text { (sec.) }\end{array}$ & $\begin{array}{l}\text { SS-S T-T } \\
\quad \text { (sec.) }\end{array}$ & Reflection Point \\
\hline $\mathrm{AKU}$ & +5.0 & -4.2 & Hudson Bay, Phanerozoic \\
\hline ANP & +5.1 & & North Pacific, $\sim 70 \mathrm{m.y}$. \\
\hline $\mathrm{BAG}$ & +3.1 & & North Pacific, $\sim 70$ m.y. \\
\hline $\mathrm{CHG}$ & +7.5 & & Kamchatka, subduction zone \\
\hline ESK & -4.3 & -9.3 & $\begin{array}{l}\text { Canadian shield, Superior prov- } \\
\text { ince }\end{array}$ \\
\hline JER & +8.8 & & Greenland shield \\
\hline IST & +4.9 & & Greenland shield \\
\hline KEV & +1.1 & & $\begin{array}{l}\text { Canadian shield, Churchill } \\
\text { province }\end{array}$ \\
\hline KTG & +1.7 & -4.1 & Hudson Bay, Phanerozoic \\
\hline MAL & +0.3 & -4.6 & $\begin{array}{l}\text { Canadian shield, Grenville } \\
\text { province }\end{array}$ \\
\hline MAT & +4.8 & & North Pacific, $\sim 70$ m.y. \\
\hline QUI & & +2.5 & East Pacific, 10-36 m.y. \\
\hline NAI & +10.6 & & North Atlantic, 53-65 m.y. \\
\hline NDI & +4.9 & & Siberian continental shelf \\
\hline NNA & +11.2 & +4.5 & Guatemala basin, $\sim 40 \mathrm{~m} . \mathrm{y}$. \\
\hline NUR & +1.4 & -3.8 & $\begin{array}{l}\text { Canadian shield, Churchill } \\
\text { province }\end{array}$ \\
\hline PTO & -3.1 & -7.9 & $\begin{array}{l}\text { Canadian shield, Grenville } \\
\text { province }\end{array}$ \\
\hline RIV & +8.5 & & Central Pacific, $\sim 100$ m.y. \\
\hline SHK & +6.8 & & North Pacific, $\sim 70$ m.y. \\
\hline SNG & +10.3 & & Kurile islands, subduction zone \\
\hline VAL & -7.6 & -11.8 & $\begin{array}{l}\text { Canadian shield, Superior prov } \\
\text { ince }\end{array}$ \\
\hline
\end{tabular}

A useful framework in which to view these SS data is within the context of ScS travel times (Okal and Anderson, 1975; Sipkin and Jordan, 1975, 1976; Okal, 1978). However, some care must be taken to properly compare $S S$ times with $S c S$ times. $S S$ samples more of the upper mantle in its propagation and reflection than $S c S$, which travels nearly vertically. For example, the propagation path of SS in the upper $225 \mathrm{~km}$ of the Earth is approximately 25 per cent longer than a vertical path. Thus, SS travel-time anomalies need to be reduced by a rough factor of 0.8 for comparison with $S c S$ data.

The method of timing the $S S$ phases in this study is different from the method employed in the $S c S$ studies. $S S$ times were picked by a waveform correlation between the observations and synthetic seismograms. Synthetic shear waves were 
generated for the earthquake source time function at the appropriate ray parameter and azimuth, and corrected for attenuation. The reference arrival time is determined from the synthetic. The synthetics are then Hilbert transformed to mimic the distortional effects at the caustic and compared to the observations. In the correlation between the observations and synthetics to pick the best arrival time, only the initial portion of the waveforms is used to minimize effects due to uncertainties in the attenuation.

The ScS times of Okal and Anderson (1975), Sipkin and Jordan (1975, 1976), and Okal (1978) are differential measurements between multiple $S c S$ and either $S c S$ or $S$. The timing method is by cross-correlation of the phase pairs. Butler (1977) has pointed out that cross-correlation timing between seismic phases which have suffered different amounts of attenuation is biased systematically late with respect to a method based upon the visual onsets of the waveforms. The approximate amount of bias is calculated by Butler (1977) comparing onset timing to cross-correlation timing using synthetic seismograms generated for a range of relative attenuations. These results are applicable in the comparison of $S c S$ times determined by crosscorrelation and $S S$ times which were determined by waveform correlation referenced to the onset time of the synthetic. Basically the $S c S$ times are about 1 to $4 \mathrm{sec}$ slower than corresponding $S S$ times, the amount of the effect being dependent upon the attenuation of $S c S$. Estimates of $Q_{\beta}$ for $S c S$ range between $Q_{\beta}=600$ (Anderson and Kovach, 1964; Kovach and Anderson, 1964) for South American data to $Q_{\beta}=$ $156 \pm 13$ (Jordan and Sipkin, 1977) for multiple $S c S$ reflections in the western Pacific. Regional differences in attenuation will vary this correction between $S S$ and $\mathrm{ScS}$ times.

The average two-way $S c S$ residual for "average ocean" (70 to $90 \mathrm{~m} . \mathrm{y}$.) is $+1.6 \mathrm{sec}$ (Okal, 1978) to $+2.4 \mathrm{sec}$ (Sipkin and Jordan, 1976). The SS data in the 70 m.y. north Pacific fall $\pm 3 \mathrm{sec}$ around the J-B baseline. The SS-S differential times for reflections beneath the Canadian shield average $6 \mathrm{sec}$ faster than $\mathrm{J}-\mathrm{B}$, and compare well with the $-4 \mathrm{sec}$ average $S c S$ residual for shields (Sipkin and Jordan, 1976). The $S S$ residuals for reflections beneath the Greenland ice cap, $+2.8 \mathrm{sec}$ and $-1.4 \mathrm{sec}$, are comparable to the oceanic values. As the exposed edges of Greenland are Precambrian shield, these slow times represent a significant exception to shield versus ocean differences proffered by Sipkin and Jordan (1976).

Although with such a sparse sampling one cannot rule out coincidence, there appear to be some systematics in the Canadian shield values. The Canadian shield is not a single structural entity; rather, it comprises seven tectonic provinces of Precambrian age, each with its own stratigraphic and structural history (Stockwell, 1964). Hudson Bay is of Phanerozoic age. Figure 8 plots the differential SS-S times in relation to these tectonic provinces; the precision of the residuals is noted in Table 4. The data naturally fall such that each of the four provinces sampled is characterized by a self-consistent, yet distinct, travel-time anomaly. This variation does not correlate with age: Superior, $\sim 2500$ m.y.; Churchill, $\sim 1700$ m.y.; Grenville, $\sim 950$ m.y.; Hudson Bay, < 600 m.y. (Stockwell, 1964). Correlations with other geophysical parameters were also unsatisfactory, including heat flow, gravity, magnetics, and postglacial uplift.

The extremal difference in the travel-time residuals to be explained, including error, is $4.5 \mathrm{sec}$ between the Churchill province (KEV) and the Superior province (VAL). For a vertical incidence this value corrects to 3.6 sec. A number of studies (see Berry, 1973; Hashizume, 1976) have been concerned with the determination of regionalized crust and upper lid velocity sections. Hashizume (1976) using surface 
waves states: "The Superior province, the Churchill province and the Hudson Platform are formed of a quite uniform crustal structure when they are measured in the scale of earth structure and regionalization assumed. The regional variations of shear velocities of the granitic and basaltic layers (middle and lower crust) of the above regions are small, less than $0.015 \mathrm{~km} / \mathrm{sec}$, whereas the regional variations of the upper-mantle velocities are a little larger. The Grenville province may have a higher velocity structure. .. " Berry and Fuchs (1973) report a seismic refraction

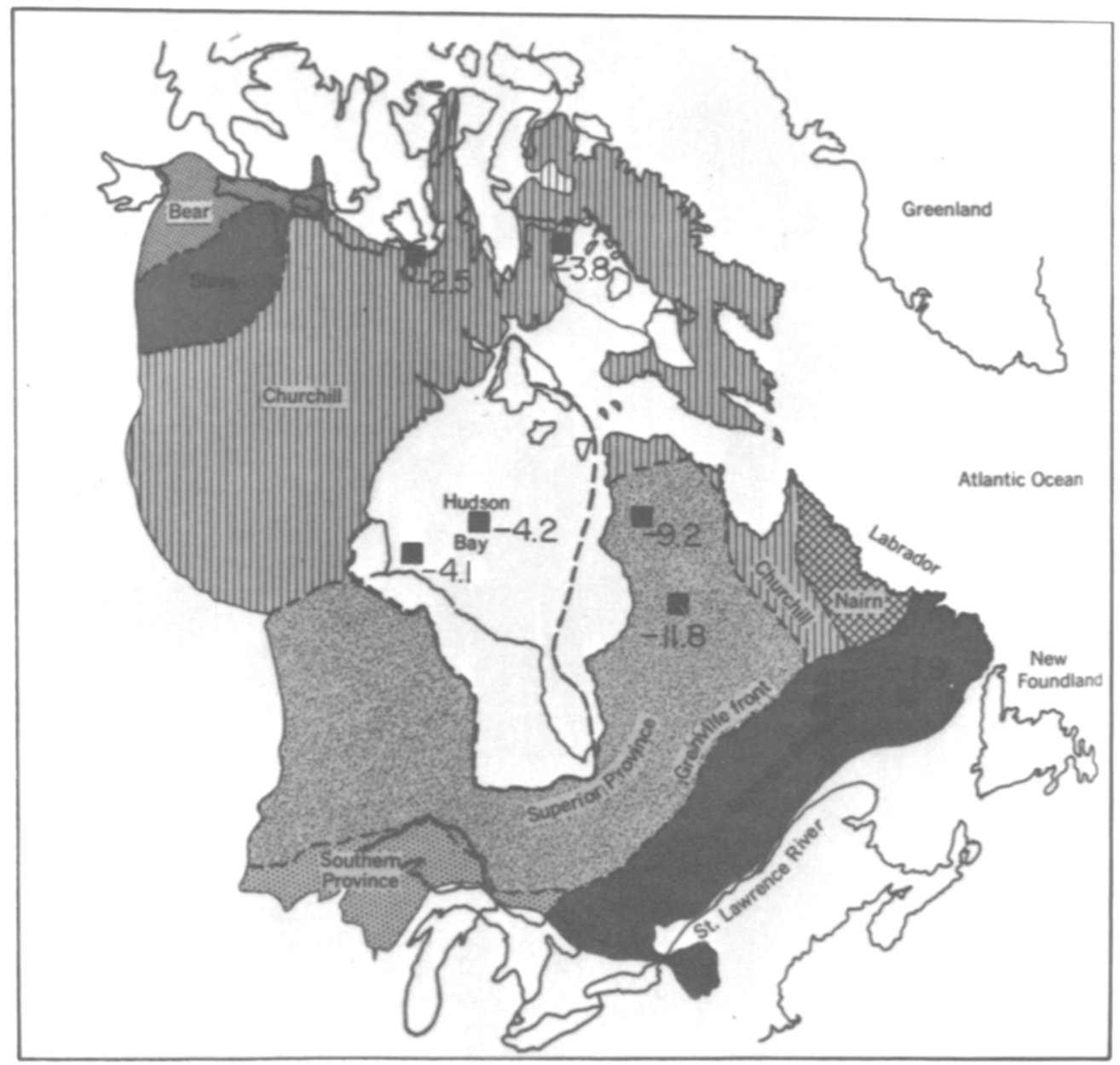

FIG. 8. Differential travel-time residuals (with respect to Jeffreys-Bullen times; negative = early) for $S S-S$ from the 1968 Borrego Mountain earthquake. The squares mark the midpoint reflection of SS in relation to structural provinces within the Canadian shield (adapted from Stockwell, 1964).

survey in the northeast Canadian shield. The average thickness of the Superior crust is $34 \mathrm{~km}$ compared to 39 for Grenville. The upper crust in the Grenville is about $0.15 \mathrm{~km} / \mathrm{sec}$ faster than the Superior (Berry and Fuchs, 1973). Using data from the Project Early Rise experiment, Mereau and Hunter (1969) determined crustal thicknesses of 30 to $35 \mathrm{~km}$ for the Superior province north of Lake Superior, thickening rapidly to values from 40 to $50 \mathrm{~km}$ north of the Superior-Churchill geological boundary. Berry (1973) reports studies indicating an average crustal thickness of $35 \mathrm{~km}$ for the Hudson platform. 
Part of the effect in our extremal difference between Superior and Churchill residuals can be accounted for by varying the crustal thickness. Assuming a thickness contrast of $15 \mathrm{~km}$ and shear-velocity contrast at the Moho of $1.1 \mathrm{~km} / \mathrm{sec}$, perhaps $2.0 \mathrm{sec}$ may be explained of the $3.6 \mathrm{sec}$ extremal difference. If we restrict variations to $225 \mathrm{~km}$ depth, the remaining 1.6 sec difference suggests a 2 per cent velocity variation in the uppermost mantle beneath the Canadian shield. This 2 per cent variation would seem to be a minimum, as this assumes an optimal case. Crustal thickness variation cannot affect differences among the Superior, Grenville, and Hudson values.

The variations must also be considerably larger if the Greenland values are fit into the framework. Even applying generous source $(6 \mathrm{sec})$ and receiver (Table 5) corrections, the JER residual remains of the order 1 sec slow with respect to J-B. A surface wave dispersion study of Greenland (Gregerson, 1970) indicates that the crust is comparable in thickness and seismic velocities to the Canadian shield.

In conclusion, the correlation between travel-time anomaly and tectonic province in the Canadian shield is uncertain until such time as additional data of corroborative nature can be obtained. However, the data are sufficiently precise to indicate lateral variations of several per cent in upper mantle velocities within stable, structural entities.

\section{ACKNOWLEDGMENT}

I would like to thank Don Helmberger and Don Anderson for their continuing interest in this research. The support of the Fannie and John Hertz Foundation is gratefully acknowledged. This research was supported by the Earth Sciences Section National Science Foundation Grant EAR 78-14786 and EAR 78-23681.

\section{REFERENCES}

Allen, C. R. and J. M. Nordquist (1972). Foreshock, main shock and larger after shocks of the Borrego Mountain earthquake, U.S. Geol. Surv., Profess. Paper 787, 16.

Anderson, D. L. and R. L. Kovach (1964). Attenuation in the mantle and rigidity in the earth's core from multiply reflected core phases, Proc. Natl. Acad. Sci., U.S. 51, 168.

Arons, A. B. and D. R. Tennie (1950). Phase distortion of acoustic pulses obliquely reflected from a medium of higher sound velocity, J. Acoust. Soc. Am. 22, 231.

Berry, M. J. (1973). Structure of the crust and upper mantle in Canada Tectonophysics $20,183$.

Berry, M. J. and K. Fuchs (1973). Crustal structure of the Superior and Grenville provinces of the northeast Canadian shield, Bull. Seism. Soc. Am. 63, 1393-1432.

Blatstein, I. M. (1971). Calculations of underwater explosion pulses at caustics, J. Acoust. Soc. Am. 49, 1568 .

Bolt, B. A. and O. W. Nuttli (1966). P wave residuals as a function of azimuth, 1, Observations, $J$. Geophys. Res. 71, 5977.

Brune, J. N. (1964) Travel times, body waves, and normal modes of the Earth, Bull. Seism. Soc. Am. 54, 2099.

Brune, J. N. (1977). Q of Shear waves estimated from S-SS spectral ratios, Geophys. Res. Letters 4, 179.

Brune, J. N. and F. Gilbert (1974). Torsional Overtone dispersion from correlations of $S$ waves and SS waves, Bull. Seism. Soc. Am. 64, 313-320.

Burdick, L. J. (1977). Broad band seismic studies of body waves, Ph.D. Dissertation, California Institute of Technology, Pasadena, $151 \mathrm{pp}$.

Burdick, L. J. and G. R. Mellman (1976). Inversion of the body waves from the Borrego Mountain earthquake to the source mechanism, Bull. Seism. Soc. Am.66, 1485-1499.

Butler, R. (1977). A source of bias in multiple $\mathrm{ScS}$ differential tunes determined by waveform correlation, Geophys. Res. Letters 4, 593.

Butler, R. (1979). Seismological studies using observed and synthetic waveforms, Ph.D. Dissertation, California Institute of Technology, Pasadena, $299 \mathrm{pp}$.

Butler, R., G. S. Stewart, and H. Kanamori (1979). The July 27, 1976, Tangshan, China earthquake--a complex sequence of intraplate events, Bull. Seism. Soc. Am. 69, 207-220.

Choy, G. L. and P. G. Richards (1975). Pulse distortion and Hilbert transformation in multiply reflected and refracted body waves, Bull. Seism. Soc. Am. 65, 55-70. 
Duschenes, J. D. and S. C. Solomon (1977). Shear wave travel time residuals from oceanic earthquakes and the evolution of oceanic lithosphere, J. Geophys. Res. 82, 1985.

Doyle, H. A. and A. L. Hales (1967). An analysis of the travel times of $S$ waves to North American stations in the distance range $28^{\circ}$ to $82^{\circ}$, Bull. Seism. Soc. Am. 57, 761-771.

Ebel, J. E. (1977). Comparison of waveforms from a foreshock-main-shock-aftershock sequence in the New Hebrides Islands, EOS Transactions 58, 1194.

Ebel, J. E., L. J. Burdick, and G. S. Stewart (1978). The source mechanism of the August 7, 1966 El Golfo earthquake, Bull. Seism. Soc. Am. 68, 1281-1292.

Fuchs, K. (1966). The transfer for $P$ waves for a system consisting of a point source in a layered medium, Bull. Seism. Soc. Am. 56, 75.

Futterman, W. I. (1962). Dispersive body waves, J. Geophys. Res. 67, 5279.

Gregerson, S. (1970). Surface wave dispersion and crust structure in Greenland, Geophys. J. 22, 29.

Hales, A. H. and J. L. Roberts (1970). Shear velocities in the lower mantle and the radius of the core, Bull. Seism. Soc. Am. 60, 1427-1436.

Harkrider, D. G. (1964). Surface waves in multilayered elastic media, I. Rayleigh and Love waves from buried sources in a multilayered elastic half-space, Bull. Seism. Soc. Am. 54, 627.

Hart, R. S. and R. Butler (1978). Shear-wave travel times and amplitudes for two well-contained earthquakes, Bull. Seism. Soc. Am. 68, 973-985.

Hashizume, H. (1976). Surface-wave study of the Canadian Shield, Phys. Earth. Planet. Interiors 11, 333.

Haskell, N. A. (1953). The dispersion of surface waves on multilayered media, Bull. Seism. Soc. Am. 43, 17.

Helmberger, D. V. (1973). Numerical seismograms of long period body waves from seventeen to forty degrees, Bull. Seism. Soc. Am. 63, 633-646.

Hill, D. P. (1974). Phase shift and pulse distortion in body waves due to internal caustics, Bull. Seism. Soc. Am. 64, 1733-1742.

Jeffreys, H. and K. E. Bullen (1940). Seismological Tables, Brit. Assoc. Adv. Sci., Gray-Milne Trust, London, $55 \mathrm{pp}$.

Jeffreys, H. and E. R. Lapwood (1957). The reflection of a pulse within a sphere, Proc. Roy. Soc. (London), Ser. A, 241, 455.

Jordan, T. H. (1975a). Lateral heterogeneity and mantle dynamics, Nature 257, 745.

Jordan, T. H. (1975b). The continental tectosphere, Rev. Geophys. Space Phys. 13, 1.

Jordan, T. H. and S. A. Sipkin (1977). Estimation of the attenuation operator for multiple ScS waves, Geophys. Res. Letters 4, 167.

Kovach, R. L. and D. L. Anderson (1964). Attenuation of shear waves in the upper and lower mantle, Bull. Seism. Soc. Am. 54, 1855.

Langston, C. A. (1976). A body wave inversion of the Koyna, India, earthquake of December 10, 1967, and some implications for body wave focal mechanisms, J. Geophys. Res. 81, 2517.

Langston, C. A. (1978). The February 9, 1971 San Fernando earthquake, a study of source finiteness in teleseismic body waves, Bull. Seism. Soc. Am. 68, 1-29.

Langston, C. A. and R. Butler (1976). Focal mechanism of the August 1, 1975 Oroville earthquake, Bull Seism. Soc. Am. 66, 1111-1120.

Langston, C. A. and D. E. Blum (1977). The April 29, 1965 Puget Sound earthquake and the crustal and upper mantle structure of western Washington, Bull. Seism. Soc. Am. 67, 693-711.

Mereau, R. F. and J. A. Hunter (1969). Crust and upper-mantle structure under the Canadian shield from Project Early Rise data, Bull. Seism. Soc. Am. 59, 147-165.

Okal, E. (1978). Seismic investigations of upper-mantle lateral heterogeneity, II, Ph.D. Dissertation, California Institute of Technology, Pasadena, $249 \mathrm{pp}$.

Okal, E. A. and D. L. Anderson (1975). A study of lateral heterogeneities in the upper-mantle by multiple ScS travel-time residuals, Geophys. Res. Letters, 2, 313.

Rial, J. A. (1978). The Caracas, Venezuela earthquake of July 1967: A multiple source event, J. Geophys. Res. 83, 5405 .

Sachs, D. A. and S. Silbiger (1971). Focusing and refraction of harmonic sound and transient pulses in stratified media, J. Acoust. Soc. Am. 49, 824.

Sengupta, M. K. (1975). The structure of the earth's mantle from body wave observations, Ph.D. Dissertation, Massachusetts Institute of Technology, Cambridge, $579 \mathrm{pp}$.

Sipkin, S. A. and T. H. Jordan (1975). Lateral heterogeneity of the upper mantle determined from the travel times of ScS, J. Geophys. Res. 80, 1474.

Sipkin, S. A. and T. H. Jordan (1976). Lateral heterogeneity of the upper mantle determined from the travel times of multiple SeS, J. Geophys. Res. 81, 6307. 
Sipkin, S. A., J. A. Orcutt, and T. H. Jordan (1978). An examination of ScS travel times with a causal Q reflectivity algorithm for SH polarized waves, EOS Transactions $\mathbf{5 9}, 324$.

Stockwell, C. H. (1964). Fourth report on structural provinces, orogenies, and time classification of the Canadian Precambrian Shield, Geol. Surv. Canada, Dept. of Mines and Technical Surveys, Paper 64-17 (Part II).

Tolstoy, I. (1968). Phase changes and pulse deformation in acoustics, J. Acoust. Soc. Am. 44, 675.

Uhrhammer, R. A. (1977). Shear wave velocity structure in the earth from differential shear wave measurements, Ph.D. Thesis, University of California, Berkeley.

SEISMOLOGICAL LABORATORY

Division OF GEOLOGICAL AND

Planetary Sciences

California Institute of Technology

Pasadena, California 91125

Contribution No. 3184

Manuscript received January 3, 1979
Present Address:

SiERra Geophysics

150 N. Santa Anita Ave.

Arcadia, California 91006

Contribution No. S6I-R-79-010 